\title{
KELAYAKAN USAHA PENGOLAHAN IKAN ASIN DI KELURAHAN SUMBER JAYA KECAMATAN KAMPUNG MELAYU KOTA BENGKULU
}

\section{BUSINESS FEASIBILITY OF SALTED FISH PROCESSING IN SUMBER JAYA VILLAGE KAMPUNG MELAYU BENGKULU CITY}

\author{
Reswita \\ Jusrusan Sosial Ekonomi Pertanian Fakultas Pertanian \\ Universitas Bengkulu \\ reswita17@yahoo.co.id
}

\begin{abstract}
The aims of this research is to analyze the feasibility of salted fish processing in Kampung Melayu Bengkulu City. The respondents in the research are 20 salted fish processors. Those respondents are conducted by purposive with the method of collecting is census method. The methods used in analyzing the data are income analysis, $R / C$ ratio, and ROI (Return of Investment). The result shows that the income from salted fish processing is about Rp.134.457,15; while the R/C ratio is 1,2; and ROI 9,76\%. From the research can be concluded that the salted fish business is feasible.
\end{abstract}

Keywords : salted fish, feasibility

\section{PENDAHULUAN}

Ikan merupakan bahan makanan yang mengandung protein yang berkualitas tinggi. Protein dalam kandungan ikan tersusun atas asam amino essensial yang diperlukan oleh tubuh sebagai sumber energi, membantu pertumbuhan dan pemeliharaan tubuh, memperkuat daya tahan tubuh, dan memperlancar proses fisiologi dalam tubuh. Dibanding dengan produk hewani lainnya, ikan memiliki beberapa kelebihan seperti memiliki kandungan protein yang cukup tinggi yaitu $20 \%$, daging ikan mudah dicerna oleh tubuh, daging ikan mengandung asam-asam lemak tak jenuh dengan kadar kolestrol yang rendah, dan daging ikan sejumlah mineral seperti $\mathrm{K}, \mathrm{Cl}, \mathrm{P}, \mathrm{S}, \mathrm{Mg}, \mathrm{Ca}, \mathrm{Fe}, \mathrm{Ma}$, $\mathrm{Zn}, \mathrm{Cu}$, vitamin A dan D. Selain memiliki banyak kelebihan, ikan juga memiliki beberapa kekurangan. Ikan merupakan salah satu bahan makanan yang mudah membusuk, bila tidak langsung diberi perlakuan dan penanganan yang tepat setelah ditangkap mutunya akan cepat menurun (Warsidi, 2008). Hal ini disebabkan karena ikan mengandung air yang cukup tinggi sehingga cepat 
rusak dan mengalami pembusukan. Hanya dalam waktu 8 jam sejak ditangkap dan didaratkan sudah akan timbul perubahan yang mengarah pada kerusakan (Adawyah, 2008).

Kekurangan yang terdapat pada ikan dapat menghambat usaha pemasaran hasil perikanan, tidak jarang menimbulkan kerugian besar terutama di saat produksi ikan melimpah. Oleh karena itu, diperlukan proses pengawetan dan pengolahan. Tujuan utama dari pengawetan dan pengolahan adalah untuk mempertahankan ikan dari proses pembusukan sehingga mampu disimpan lama, meningkatkan jangkauan pemasaran, melaksanakan diversifikasi pengolahan produk-produk perikanan, dan meningkatkan pendapatan. Afrianto dan Liviawati (1994), menyatakan tujuan dari proses pengawatan dan pengolahan adalah memperpanjang daya tahan dan daya simpan ikan. Selain itu, proses pembuatan diperlukan untuk meningkatkan nilai tambah, baik dari segi gizi, rasa, bau, bentuk/tekstur, maupun daya awet. Hasil penelitian Soejono (2008) menunjukkan bahwa pengolahan ikan menjadi ikan kering dapat meningkatkan nilai tambah sebesar 29,6\%.

Salah satu bentuk pengawet dan pengolahan ikan adalah dengan mengasinkan ikan-ikan tersebut. Dengan mengasinkan ikan-ikan tersebut dengan garam, ikan-ikan tersebut akan tahan lebih lama, selain itu juga meningkatkan nilai jual (Nyoman, 2007). Selain keuntungan yang menjanjikan, ikan asin juga sangat disenangi oleh masyarakat.

Kecamatan Kampung Melayu merupakan salah satu daerah di Kota Bengkulu yang sebagian besar penduduknya bekerja sebagai pembuat ikan asin. Daerah tersebut terletak dekat pelabuhan Pulau Baai yang setiap harinya banyak menyediakan ikan segar untuk bahan baku pembuatan ikan asin. Usaha pembuatan ikan asin di Kampung Melayu ini sebagian besar dilakukan oleh nelayan tradisional dengan skala kecil atau usaha rumah tangga. Jenis ikan asin yang dibuat adalah ikan teri, ikan kase, ikan beledang dan ikan dencis. Untuk melihat apakah usaha tersebut menguntungkan atau tidak, maka perlu dilakukan studi tentang analisis usaha pembuatan ikan asin. Dengan demikian tujuan penelitian ini adalah untuk menganalisis kelayakan usaha pembuatan ikan asin di Kelurahan Sumber Jaya Kecamatan Kampung Melayu Kota Bengkulu.

\section{METODOLOGI PENELITIAN}

Penelitian ini dilakukan di Kelurahan Sumber Jaya Kecamatan Kampung Melayu Kota Bengkulu pada bulan Februari sampai Maret 2012. Jumlah responden sebanyak 20 orang pembuat ikan asin. Data yang digunakan adalah data primer, yaitu data yang diperoleh langsung dari responden melalui wawancara dengan menggunakan daftar pertanyaan (kuesioner) dan data sekunder, yaitu dari studi literatur yang berkaitan dengan penelitian. 


\section{Metode Analisis Data}

\section{Analisis pendapatan usaha pembuatan ikan asin}

Pendapatan dihitung dengan rumus yang diformulasikan oleh Soekartawi (1995) sebagai berikut :

$$
\begin{aligned}
& \pi=T R-T C \\
& T R=Y . P y \text { dan } T C=F C+V C
\end{aligned}
$$

dimana TR adalah Total penerimaan (Rp per periode produksi), $\mathrm{Y}$ adalah Produksi (Kg per periode produksi), Py adalah Harga output (Rp perkg), TC adalah Total Biaya (Rp per periode produksi), FC adalah Total Biaya Tetap (Rp per periode produksi), dan VC adalah Total Biaya Variabel (Rp per periode produksi)

\section{Analisis kelayakan usaha pembuatan ikan asin}

Untuk mengetahui kelayakan usaha (aspek ekonomi) pembuatan ikan asin, maka dilakukan analisis R/C Rasio (Revenue Cost Ratio) dan analisis ROI (Return of Investment).

\section{Analisis R/C Rasio}

Efisiensi usaha ditunjukkan oleh perbandinngan besarnya penerimaan dan biaya yang dikeluarkan yang kemudian disebut Revenue Cost (R/C). Menurut Soekartawi (1995) efisiensi usaha dapat diketahui dengan membandingkan antara penerimaan dengan biaya yang dikeluarkan, sehingga efisiensi usaha dapat dirumuskan:

$$
R / C^{\text {rasio }}=\frac{\mathrm{TR}}{\mathrm{TC}}
$$

Semakin tinggi Rasio R/C berarti usaha tersebut semakin efisien. Jika R/C > 1 maka usaha tersebut mengalami keuntungan/efisien, $\mathrm{R} / \mathrm{C}<$ 1 artinya usaha tersebut mengalami kerugian/tidak efisien, dan $\mathrm{R} / \mathrm{C}=1$ maka usaha tersebut mengalami impas.

\section{Analisis ROI}

ROI adalah keuntungan yang diperoleh dari sejumlah modal. Nilai ini dapat digunakan untuk mengetahui efisiensi penggunaan modal. Adapun rumus ROI dalam Rahardi, dkk (1999) adalah:

$$
R O I=\frac{\text { Laba Usaha }}{\text { Modal }}
$$




\section{HASIL DAN PEMBAHASAN}

\section{Proses Pembuatan Ikan Asin}

Tahap-tahap kegiatan pembuatan ikan asin adalah sebagai berikut :

\section{Pembersihan}

Pada tahap ini, pembersihan yang dilakukan adalah pencucian dengan menggunakan air sampai bersih, yang dilakukan pada bak-bak. Setelah bersih bahan baku ikan-ikan tersebut dimasukkan ke tempat yang disediakan yaitu ember-ember besar.

\section{Penggaraman}

Penggunaan garam dalam pembuatan ikan asin berfungsi sebagai pengawet. Sebagai pengawet, garam dapat mengurangi kadar air yang terkandung dalam ikan sehingga dapat menghambat pertumbuhan mikroba dan menghambat aktivitas enzim. Garam yang digunakan dalam pembuatan ikan asin adalah garam dapur atau garam murni $(\mathrm{NaCl})$. Penggunaan garam yang murni akan menghasilkan ikan asin yang berwarna putih dan bertekstur lunak. Jika direndam dalam air, ikan asin akan cepat menyerap air sehingga bila digoreng akan berasa seperti ikan segar (Astawan, 2004). Perbandingan antara bahan baku dengan garam adalah $1: 2$, jadi untuk $1 \mathrm{~kg}$ ikan dibutuhkan garam sebanyak $2 \mathrm{~kg}$.

\section{Penjemuran (Pengeringan)}

Ikan yang telah diberi garam, kemudian dicuci bersih dan langsung dijemur di atas para-para. Tempat penjemuran bebas dari naungan dengan tujuan agar sinar matahari dapat digunakan seluruhnya secara langsung. Parapara dibuat dari bambu yang telah dibelah-belah. Aktivitas penjemuran yang bertujuan untuk mengeringkan ikan ini harus dibarengi dengan proses pembalikan yang minimum dilakukan 2-3 kali setiap harinya. Sebelum ikan betul-betul kering, setiap sore ikan-ikan tersebut diletakkan di tempat yang beratap dengan tujuan tidak tersiram air hujan. Lamanya penjemuran tergantung dari keadaan cuaca tetapi umumnya dibutuhkan waktu 2-3 hari.

\section{Karakteristik Responden}

Umur responden rata-rata 34 tahun. Usia ini masih tergolong usia produktif yang memungkinkan pengolah ikan asin bekerja secara optimal untuk mengembangkan usahanya. Tingkat pendidikan formal responden ratarata 9,6 tahun atau setingkat SLTA. Tingkat pendidikan formal akan berpengaruh terhadap daya adopsi dan inovasi dalam pengelolaan usaha. Pengalaman responden dalam mengolah ikan asin rata-rata 5,6 tahun. 
Pengalaman ini dapat membantu pengolah dalam pengambilan keputusan, dan pengolah akan cenderung belajar dari pengalaman sebelumnya sehingga ia memiliki gambaran tentang apa yang akan dilakukan bagi peningkatan produktifitas usahanya. Jumlah tanggungan keluarga responden rata-rata 4,3 orang. Jumlah tanggungan keluarga akan memberikan motivasi bagi pengolah ikan asin untuk berupaya meningkatkan pendapatan usahanya.

\section{Penggunaan Modal dalam Usaha Pembuatan Ikan Asin}

Jumlah keseluruhan modal yang digunakan dalam satu kali proses pembuatan ikan asin sebesar Rp. 1.390.104,00. Modal terdiri dari modal tetap dan modal kerja (operasional).

\section{Modal Tetap (Investasi)}

Modal tetap yang digunakan dalam pembuatan ikan asin adalah waring bambu, pisau, ember, dan keranjang. Jumlah modal tetap yang digunakan berjumlah Rp. 716.650/periode produksi. Modal tetap terbesar yang dikeluarkan pengolah ikan asin adalah untuk pembelian waring yaitu sebesar $52,18 \%$. Waring digunakan untuk tempat menjemur ikan asin.

\section{Tabel 1. Penggunaan Modal dalam Usaha Pembuatan Ikan Asin per} Periode Produksi

\begin{tabular}{clrc}
\hline No & \multicolumn{1}{c}{ Modal Tetap } & Jumlah $(\mathrm{Rp})$ & Persentase(\%) \\
\hline 1 & Waring & 375.000 & 52,18 \\
2 & Bambu & 221.429 & 30,81 \\
3 & Pisau & 12.375 & 1,72 \\
4 & Ember & 53.900 & 7,50 \\
5 & Keranjang & 55.950 & 7,79 \\
\hline \multicolumn{2}{r}{ Total } & 718.650 & 100,00
\end{tabular}

Sumber : Data primer diolah

\section{Modal Kerja atau Modal Operasional}

Modal kerja termasuk ke dalam biaya tidak tetap yang dikeluarkan oleh pengusaha ikan asin untuk pembelian ikan, garam, tenaga kerja, dan transportasi. Rata-rata modal kerja untuk satu kali proses produksi sebesar Rp. 671.450 . 
ISSN: $1412-8837$

Tabel 2. Penggunaan Modal Operasional dalam Usaha Pembuatan Ikan Asin per Periode Produksi

\begin{tabular}{clcc}
\hline No & Modal Operasional & Jumlah $(\mathrm{Rp})$ & Persentase (\%) \\
\hline 1 & Biaya pembelian ikan & 551.200 & 82,09 \\
2 & Biaya pembelian garam & 25.156 & 3,75 \\
3 & Biaya tenaga kerja & 80.000 & 11,91 \\
4 & Biaya transportasi & 15.094 & 2,25 \\
\hline & Total & 671.450 & 100,00 \\
\hline
\end{tabular}

Sumber : Data primer diolah

\section{Total Modal}

Total modal adalah penjumlahan dari modal tetap dan modal operasional. Keseluruhan modal dalam usaha pengolahan ikan asin ini adalah sebesar Rp. 1.390 .100 per periode produksi

\section{Biaya Usaha Pembuatan Ikan Asin}

Total biaya usaha pembuatan ikan asin adalah seluruh biaya yang dikeluarkan selama proses produksi berlangsung. Biaya total adalah penjumlahan biaya tetap dan biaya variabel yang dikeluarkan pengolah ikan asin untuk satu kali proses produksi.

Tabel 3. Total Biaya Usaha Pembuatan Ikan Asin per Periode Produksi

\begin{tabular}{|c|c|c|c|}
\hline No & Biaya Usaha & Jumlah (Rp) & $\begin{array}{c}\text { Persentase } \\
(\%)\end{array}$ \\
\hline \multirow[t]{2}{*}{1} & Biaya Tetap & & \\
\hline & Biaya penyusutan alat & $1.286,60$ & 0,19 \\
\hline \multirow[t]{10}{*}{2} & Biaya Variabel & & \\
\hline & 1. Biaya pembelian ikan & $551.200,00$ & 81,93 \\
\hline & a. Ikan teri $\quad 12,59 \mathrm{~kg} \times \mathrm{Rp} 18.000=226.575$ & & \\
\hline & b. Ikan sarden $12,41 \mathrm{~kg} \times \mathrm{Rp} .14 .000=173.775$ & & \\
\hline & c. Ikan beledang12,40 kg x Rp. $8.000=99.200$ & & \\
\hline & $12.91 \mathrm{~kg} \times \mathrm{Rp} .4 .000=51.650$ & & \\
\hline & 2. Biaya pembelian garam & $25.156,00$ & 3,74 \\
\hline & 3. Biaya tenaga kerja & $80.000,00$ & 11,89 \\
\hline & 4. Biaya transportasi & $15.094,00$ & 2,24 \\
\hline & Total & $672.736,60$ & 100,00 \\
\hline
\end{tabular}

Sumber : Data primer diolah

252 | Reswita, Kelayakan Usaha Pengolahan Ikan Asin di Kelurahan ... 
Jumlah biaya yang terserap dalam satu kali proses pembuatan ikan asin di Kelurahan Sumber Jaya Kecamatan Kampung Melayu Kota Bengkulu adalah Rp. 672.736,60. Biaya pembelian bahan baku merupakan biaya yang terbesar $(81,93 \%)$. Kemudian diikuti oleh biaya tenaga kerja sebesar $11,89 \%$.

\section{Penerimaan}

Penerimaan usaha pembuatan ikan asin berasal dari hasil penjualan ikan teri, ikan sarden, ikan beledang, dan ikan kase asin. Penerimaan merupakan jumlah produksi dikalikan dengan harga jual masing-masing jenis ikan asin. Rata-rata jumlah produksi setiap jenis ikan asin yang dihasilkan adalah $11 \mathrm{~kg}$. Rata-rata penerimaan dalam satu kali periode produksi adalah $\mathrm{Rp} 807.250$

Tabel 4. Rata-rata Penerimaan Usaha Pembuatan Ikan Asin per Periode Produksi

\begin{tabular}{clccr}
\hline $\begin{array}{c}\mathrm{N} \\
\mathrm{o}\end{array}$ & Jenis Ikan Asin & Produksi (Kg) & $\begin{array}{c}\text { Harga jual } \\
(\mathrm{Rp} / \mathrm{Kg})\end{array}$ & $\begin{array}{c}\text { Total Penerimaan } \\
(\mathrm{Rp})\end{array}$ \\
\hline 1 & Ikan teri & 10,99 & 29.000 & 318.710 \\
2 & Ikan Sarden & 11,00 & 24.000 & 264.000 \\
3 & Ikan beledang & 10,95 & 14.000 & 153.300 \\
4 & Ikan kase & 10,96 & 6.500 & 71.240 \\
\hline & Total & 43,90 & & 807.250 \\
\hline
\end{tabular}

Sumber : Data primer diolah

\section{Pendapatan}

Pendapatan adalah selisih antara penerimaan dan biaya. Rata-rata pendapatan yang diperoleh dari usaha pembuatan ikan asin adalah sebesar Rp. $134.457,15$ dalam satu kali proses produksi. Frekuensi pembuatan setiap bulan rata-rata 12 kali sehingga dalam satu bulannya rata-rata pendapatan usaha pembuatan ikan asin sebesar Rp. 1.614.040,80.

Tabel 4. Rata-rata Pendapatan dalam Usaha Pembuatan Ikan Asin

\begin{tabular}{rlcc}
\hline \multicolumn{1}{c}{ No } & \multicolumn{1}{c}{ Uraian } & Jumlah $(\mathrm{Rp} /$ periode produksi) & Jumlah $(\mathrm{Rp} /$ bulan $)$ \\
\hline 1 & Penerimaan & $807.250,00$ & $9.687 .000,00$ \\
2 & Biaya & $672.736,60$ & $8.072 .959,20$ \\
3 & Pendapatan & $134.457,15$ & $1.614 .040,80$ \\
\hline
\end{tabular}

Sumber : Data primer diolah 


\section{Kelayakan Usaha Pembuatan Ikan Asin}

\section{Perhitungan R/C Rasio}

Hasil estimasi didapatkan nilai RC Rasio sebesar 1,2. Nilai ini berarti dengan modal Rp. 672.736,60 diperoleh hasil penjualan sebesar 1,2 kalinya. Hasil ini tidak jauh berbeda dari hasil penelitian Hendrik (2010), dimana dari analisis kelayakan usaha pembuatan ikan asin yang dilakukan di Kecamatan Pandan Kabupaten Tapanuli Tengah diperoleh RC Rasio sebesar 1,26. Nilai R/C Rasio > 1 menunjukkan usaha ini layak untuk dikembangkan. Dengan demikian, usaha pembuatan asin yang dilakukan oleh masyarakat di Kampung Melayu menguntungkan dan layak untuk dikembangkan.

\section{Perhitungan ROI}

ROI digunakan untuk mengukur efektifitas usaha di dalam menghasilkan keuntungan dengan memanfaatkan modal yang dimiliki. Semakin besar ROI menunjukkan kinerja yang semakin baik, karena tingkat pengembalian modal semakin besar. Nilai ROI sebesar 9,67\% menunjukkan bahwa kemampuan modal menghasilkan laba sebesar 9,67\%. Suatu usaha dikatakan mempunyai kemampuan tinggi dalam menghasilkan laba apabila nilai ROI lebih besar dari 1. Nilai ROI usaha pembuatan ikan asin sebesar 9,67\% berarti usaha pembuatan ikan asin mempunyai kemampuan laba yang cukup tinggi. Dari Rp 10,000 modal yang diinvestasikan akan menghasilkan keuntungan sebesar Rp. 967. Dibandingkan hasil penelitian Resmiati, dkk (2003), kemampuan menghasilkan keuntungan di Kelurahan Sumber Jaya Kecamatan Kampung Melayu relatif lebih rendah dari usaha pengolahan ikan asin di di Desa Karanghantu Serang Provinsi Banten yang nilai ROInya sebesar $33 \%$.

\section{SIMPULAN DAN SARAN}

\section{Simpulan}

Dari hasil penelitian diketahui pendapatan yang diperoleh dari pembuatan ikan asin sebesar Rp.134.457,15 dalam satu kali proses produksi. Frekuensi pembuatan setiap bulan rata-rata 12 kali dan dalam satu bulannya rata-rata pendapatan pengolah ikan asin sebesar Rp. 1.614.040,80, R/C ratio sebesar 1,2 dan ROI sebesar 9,76\% sehingga dapat disimpulkan usaha pembuatan ikan asin layak untuk dikembangkan.

\section{Saran}

Usaha pengolahan ikan asin di Kelurahan Sumber Jaya Kecamatan Kampung Melayu Kota Bengkulu layak untuk dikembangkan lebih lanjut. 


\section{DAFTAR PUSTAKA}

Adawyah, R. 2008. Pembuatan dan Pengawetan Ikan. PT. Bumi Aksara. Jakarta.

Afrianto, E. dan Liviawaty. 1994. Pengawetan dan Pembuatan Ikan. Kanisius. Yogyakarta.

Hendrik. 2010. Analisis Usaha Pembuatan Ikan Asin di Kecamatan Pandan Kabupaten Tapanuli Tengah Sumatera Utara. Jurnal Perikanan dan Kelautan; 15, 11 (2010). http://ejournal.unri.ac.id/index.php/JPK/article/view/33. Diakses 20 Juni 2013

Nyoman, S. 2007. Perikanan. SIC. Surabaya.

Resmiati, Teti., Skalalis Diana, dan Sei Astuty. 2003. Pengasinan Ikan Teri (Stolephorus spp.) dan kelayakan Usahanya di desa Karanghantu Serang. Laporan penelitian Universitas Padjajaran.

Rahardi, F., Regina Kristiawati, dan Nazaruddin .1999. Agribisnis Perikanan. PT. Penebar Swadaya. Bogor.

Sutarmi. 2013. Faktor-faktor yang Mempengaruhi Produksi Pengawetan Ikan Asin di Kecamatan Labuhan Meringgai Kabupaten Lampung Timur. Jurnal Ilmiah ESAI; Volume 7 No.1 Januari 2013. ISSN No. 1978-6034. Jurusan Ekonomi dan Bisnis Politeknik Negeri Lampung.

Soejono, D. 2008. Pola Pengembangan Agroindustri Berbasis Perikanan Laut di Kecamatan Puger Kabupaten Jember. Jurnal J-SEP. Volume 2 No. 1 Maret 2008. http://jurnal.unej.ac.id/index.php/JSEP/article/view/415. Diakses 25 Juni 2014.

Soekartawi. 1995. Analisa Usahatani. UI-Press. Jakarta.

Warsidi, E. 2009. Bagaimana Mengolah dan Mengawetkan Ikan. Mitra Utama. Bekasi. 